\title{
Estimation of direct and maternal genetic parameters for weaning weight in Hungarian Simmental cattle
}

\author{
Afees A. Ajasa ${ }^{1}$ - Imre Füller ${ }^{2}$ - Barnabás Vágó ${ }^{2}$ - István Komlósi ${ }^{1}$ - János Posta ${ }^{1 *}$ \\ ${ }^{1}$ Department of Animal Husbandry, Institute of Animal Science, Biotechnology and Natural Conservation, Faculty of Agricultural and Food \\ Sciences and Environmental Management, University of Debrecen, Debrecen, Hungary \\ ${ }^{2}$ Association of Hungarian Simmental Breeders, Bonyhád, Hungary \\ *Correspondence: postaj@agr.unideb.hu
}

\begin{abstract}
SUMMARY
The aim of the current research was to estimate variance components and genetic parameters of weaning weight in Hungarian Simmental cattle. Weaning weight records were obtained from the Association of Hungarian Simmental Breeders. The dataset comprised of 44,278 animals born from 1975 to 2020. The data was analyzed using the restricted maximum likelihood methodology of the Wombat software. We fitted a total of six models to the weaning weight data of Hungarian Simmental cattle. Models ranged from a simple model with animals as the only random effect to a model that had maternal environmental effects as additional random effects as well as direct maternal genetic covariance. Fixed effects in the model comprised of herd, birth year, calving order and sex. Likelihood ratio test was used to determine the best fit model for the data. Results indicated that allowing for direct-maternal genetic covariance increases the direct and maternal effect dramatically. The best fit model had direct and maternal genetic effects as the only random effect with non-zero direct-maternal genetic correlation. Direct heritability, maternal heritability and direct maternal correlation of the best fit model was $0.57,0.16$ and -0.78 respectively. The result indicates that problem of (co-)sampling variation occurs when attempting to partition additive genetic variance into direct and maternal components.
\end{abstract}

Keywords: Variance components; genetic parameters; Hungarian Simmental cattle

\section{INTRODUCTION}

Weaning weight is an economically important trait in cattle breeding. The selection for higher weight at young ages can increase the mature weight due to genetic correlations from medium to high magnitudes between weights in different ages (Silva et al., 2000; Boligon et al., 2009; Meyer, 1992). In other words, they are good indicators of animal growth potentials at older ages (Baldi et al., 2010). The weaning weight (WW) is often used as a correlated trait in genetic evaluation programs and is used for decision-making on culling or selection (Guidolin et al., 2012). Weaning weight is easy to obtain (Boligon et al., 2009) and has a medium heritability which results in a high selection response (Szabo et al., 2002). The weaning weight is not only a function of the offspring genotype but also the maternal environment. This can be referred to as direct and maternal effect respectively. Any influences from dam to progeny, excluding the effects of directly transmitted genes are referred to as maternal genetic effects (Szwaczkowski et al., 2006; Legates, 1972). From the perspective of the offspring, maternal effects are purely environmental (Gholizadeh et al., 2010; Eaglen \& Bijma, 2008). Maternal effects play a role in the growth of an offspring until they are weaned (Koch and Clark, 1955). Not accounting for maternal effects in genetic evaluation model results in an upward bias estimate of genetic parameters for weaning weight (Khombe et al., 1995; Robinson, 1996a) which can hamper efficiency of selection. Both direct and maternal effects should be taken into consideration to realize the optimum genetic improvement in selection programs (Robison, 1981). The Hungarian Simmental cattle is a major cattle breed in Hungary with about 65,000 individuals (Anton et al.,
2018). It is a dual-purpose breed i.e. it is breed for both meat and milk (Anton et al., 2018). There are few reports about genetic parameters accounting for the maternal effect, hence, this research aims to estimate the direct and maternal genetic effect on weaning weight of Hungarian Simmental cattle.

\section{MATERIALS AND METHODS}

Weaning weight of Hungarian Simmental animals born between 1975 and 2020 were obtained from the Association of Hungarian Simmental Breeders. The dataset comprised of 44,278 Hungarian Simmental animals. The mean, standard deviation and coefficient of variation of the weaning weight was $213.08 \mathrm{~kg}$, 46.77 and $22.25 \%$, respectively. The pedigree file consisted of 56,406 animals with 879 sires and 14811 dams and average inbreeding coefficient is $0.41 \%$.

\section{Statistical Analysis}

In order to decide on which fixed effects to be included in the model, preliminary test was performed using the analysis of variance command of the $R$ package (R Core Team, 2021). Effects not significant were eliminated from the model. Finally, the fixed effects used in the model were herd ( 92 level), birth year (46), calving order (15) and sex (2) as they had a significant effect $(\mathrm{P}<0.05)$ on the weaning weights.

The models used in matrix notation were:

$$
\begin{aligned}
& \mathbf{y}=\mathbf{X b}+\mathbf{Z a}+\mathrm{e} \\
& \mathbf{y}=\mathbf{X b}+\mathbf{Z a}+\mathbf{S p e}+\mathrm{e} \\
& \mathbf{y}=\mathbf{X b}+\mathbf{Z a}+\mathbf{W m}+\mathrm{e}, \text { with } \sigma(\mathrm{a}, \mathrm{m})=0
\end{aligned}
$$




$$
\begin{aligned}
& \mathbf{y}=\mathbf{X b}+\mathbf{Z a}+\mathbf{W m}+\mathrm{e} \\
& \mathbf{y}=\mathbf{X b}+\mathbf{Z a}+\mathbf{W m}+\mathbf{S p e}+\mathrm{e}, \text { with } \sigma(\mathrm{a}, \mathrm{m})=0 \\
& \mathbf{y}=\mathbf{X b}+\mathbf{Z a}+\mathbf{W m}+\mathbf{S p e}+\mathrm{e}
\end{aligned}
$$

Where $\mathbf{y}$ is a vector of observation, $b$ is a vector of fixed effects, $\mathrm{a}$ is a vector of random animal effects, $\mathrm{m}$ is a vector of maternal effects, pe is a vector of permanent environmental effects. $\mathbf{X}, \mathbf{Z}, \mathbf{W}, \mathbf{S}$ are incidence matrices relating records to fixed, animal, maternal and permanent environmental effects, respectively.

The (co)variance structure of the analysis is

$$
\begin{aligned}
& \operatorname{Var}(\mathrm{a})=\mathbf{A} \sigma_{\mathrm{a}} \\
& \operatorname{Var}(\mathrm{m})=\mathbf{A} \sigma_{\mathrm{m}} \\
& \operatorname{Var}(\mathrm{pe})=\mathbf{I} \sigma_{\mathrm{pe}} \\
& \operatorname{Var}(\mathrm{e})=\mathbf{I} \sigma_{\mathrm{e}} \\
& \operatorname{Cov}(\mathrm{a}, \mathrm{m})=\mathbf{A} \sigma_{\mathrm{AM}}
\end{aligned}
$$

Where $\mathbf{A}$ is the numerator relationship matrix and $\mathbf{I}$ is an identity matrix. $\sigma_{\mathrm{a}}$ is the additive/direct genetic variance, $\sigma_{\mathrm{m}}$ is the maternal genetic variance, $\sigma_{\mathrm{pe}}$ is maternal permanent environmental variance, $\sigma_{\mathrm{e}}$ is the residual variance and $\sigma_{\mathrm{AM}}$ is covariance between direct and maternal effects.

The first model (Model 1) was a simple animal model with direct genetic effect as the only random effect. Model 2 included a permanent maternal environment as an additional random effect. Model 3 on the one hand had both the animal effect and the maternal effect as random effects, with their covariance is being zero. Model 4 on the other hand was similar to Model 3 but the covariance between direct and maternal effect is assumed to be non-zero. Model 5 and 6 were similar to each other i.e. both of them have animal, maternal and permanent environmental effects as random. However, while Model 5 assumed that animal and maternal effects were not correlated, Model 6 assumed that they were correlated.

The Restricted Maximum Likelihood method of the Wombat software (Meyer, 2007) was used to estimate the various (co)variance components. At convergence restarts were initiated to ensure that it is global minimum.

Likelihood test was conducted to determine which effect was significant and consequently warrants inclusion in the model.

Total heritability was estimated as defined by Willham (1972) as

$$
\mathrm{h}_{\mathrm{T}}=\left(\sigma_{\mathrm{a}}^{2}+0.5 * \sigma_{\mathrm{m}}^{2}+1.5 * \sigma_{\mathrm{am}}\right) / \sigma_{\mathrm{P}}^{2},
$$

where the phenotypic variance $\left(\sigma_{\mathrm{p}}^{2}\right)$ was:

$$
\sigma_{\mathrm{a}}^{2}+\sigma_{\mathrm{m}}^{2}+\sigma_{\mathrm{am}}+\sigma_{\mathrm{e}}^{2}
$$

\section{RESULTS AND DISCUSSION}

The mean weight of the Hungarian Simmental beef calves obtained in this study $(213.08 \mathrm{~kg})$ was similar what was reported by Kebede \& Komlosi (2015) in a similar Hungarian Simmental population who reported a weaning weight of $211 \mathrm{~kg}$. Conversely, Bene et al. (2010) and Szabo et al. (2012) reported a value of 217 $\mathrm{kg}$ and $236 \mathrm{~kg}$ respectively in a smaller sized population of Hungarian Simmental cattle. Though the estimates are somewhat close, the difference could be as a result of sampling variance. The coefficient of variation found in this study was in agreement with earlier findings by Bene et al. (2010) and Kebede \& Komlosi (2015) in Hungarian Simmental beef calves. Contrarily, Szabo et al. (2012) reported a lower value.

Estimate of the (co)variance, genetic parameters are presented in Table 1. As shown in the log likelihood estimate the best model i.e. Model 4 included only the direct and maternal effects and allowed for their covariance. From the best model (Model 4) it can be implied that the permanent environmental effect of the dam is not important for the weaning weights of the Hungarian Simmental cattle. The direct heritability estimates from this model revealed that a considerable amount of the variation in weaning weight can be attributed to the additive genetic variance which indicates that genetic improvement through selection can be achieved.

The direct heritability estimate of the best model (Model 4) is somewhat higher than what is generally found in the literature 0.37 (Szabo et al., 2012), 0.27 (Intaratham et al., 2008), 0.25 (Ndofor-Foleng et al., 2012), 0.19 (Van Niekerk \& Neser, 2006) and 0.30 (Tramonte et al., 2019) in Hungarian Simmental, Northeastern Thai indigenous, Gudali, South African Limousin, and Guzera cattle respectively. Nevertheless, the estimate reported in this study agreed with an earlier conclusion by Wasike et al. (2006) in Kenyan Boran cattle (0.6) and Szabo et al. (2007) in Charolais cattle population (0.6) in Hungary. Wasike et al. (2006) attributed the high direct heritability estimate they obtained to be a result of the high genetic variability in the population examined. Skrypzeck et al. (2000) while commenting on the high direct heritability observed in their study noted that multibreed composition of the herd and consequently the noninclusion of the dominance effect in the model could be a reason for the high estimates. Maternal environment comprises mainly of dam's milk yield, lactation length and mothering ability. Maternal heritability estimate (0.16) was moderate suggesting a slow response when used as a selection criterion. Similar estimate was reported by Campelo et al. (2004), Sarmiento \& Garcia (2007), Herrera-Ojeda et al. (2019) and Lopez et al. (2020) in Tabapua, Romosinuano, Charolais and Hanwoo cattle respectively. The heritability of the maternal effect was lower than the direct effect, this corroborates the findings of Skrypzeck et al. (2000), Szabo et al. (2007), Neser et al. (2012) and Brito et al. (2020) who noted an estimate of $0.21,0.32,0.11,0.05$ in multi composite breed, Charolais, Brangus and 
Guzera cattle respectively. This suggests that a calf's genotype is more important than the maternal environment which consist mainly of the dam milk yield in the determination of its weaning weight. Although the maternal heritability is lower than the direct heritability in this result, the former should not be ignored in genetic evaluation of weaning weight.

The maternal permanent environment was found to be of no significance in this study. This is in agreement with report by Khorshidi et al. (2020) in Hays converter cattle. Conversely, significant maternal permanent environmental effect were found in multibreed beef (Skrypzeck et al., 2000; Vergara et al., 2009; Dadi et al., 2004), Bonsmara (Maiwashe et al., 2002), Charolais (Crews et al., 2004), Red Angus (Boldt et al., 2018), Guzera (Brito et al., 2020), Boran (Wasike et al., 2009) and Nellore (Kamei et al., 2017) cattle. In some cases, the permanent environmental effect was more important than the maternal genetic effect (Dadi et al., 2004; Crews et al., 2004; Kamei et al., 2017; Boldt et al., 2018).

Table 1. Estimate of variance component and genetic parameters for weaning weight

\begin{tabular}{|c|c|c|c|c|c|c|}
\hline Weaning weight & Model 1 & Model 2 & Model 3 & Model 4 & Model 5 & Model 6 \\
\hline $\begin{array}{l}\text { Direct genetic variance } \\
\left(\sigma_{\mathrm{a}}^{2}\right)\end{array}$ & 545.3 & 517.1 & 477.2 & 999.4 & 477.2 & 1002.6 \\
\hline $\begin{array}{ll}\text { Maternal } & \text { genetic } \\
\text { variance }\left(\sigma_{\mathrm{m}}^{2}\right) & \end{array}$ & & & 71.7 & 280.8 & 71.7 & 262.5 \\
\hline $\begin{array}{l}\text { Maternal permanent } \\
\text { environmental variance } \\
\left(\sigma_{\text {pe }}^{2}\right)\end{array}$ & & 37.4 & & & 0.001 & 19.1 \\
\hline Residual variance $\left(\sigma_{\mathrm{e}}^{2}\right)$ & 1142.7 & 1129.2 & 1134.9 & 880.7 & 1134.9 & 872.9 \\
\hline $\begin{array}{l}\text { Direct maternal } \\
\text { covariance }\left(\sigma_{\mathrm{AM}}\right)\end{array}$ & & & & -415.80 & & -414.11 \\
\hline Phenotypic variance $\left(\sigma_{\mathrm{p}}^{2}\right)$ & 1688.0 & 1683.8 & 1683.7 & 1745.0 & 1683.7 & 1742.9 \\
\hline Direct heritability $\left(\mathrm{h}_{\mathrm{a}}^{2}\right)$ & 0.32 & 0.30 & 0.28 & 0.57 & 0.28 & 0.58 \\
\hline $\begin{array}{l}\text { Maternal heritability } \\
\left(\mathrm{h}_{\mathrm{m}}^{2}\right)\end{array}$ & & & 0.04 & 0.16 & 0.04 & 0.15 \\
\hline $\mathrm{C}_{\mathrm{AM}}\left(\sigma_{\mathrm{AM}} / \sigma_{\mathrm{P}}^{2}\right)$ & & & & -0.24 & & -0.24 \\
\hline $\begin{array}{l}\text { Direct maternal genetic } \\
\text { correlation }\left(\mathrm{r}_{\mathrm{am}}\right)\end{array}$ & & & & -0.78 & & -0.81 \\
\hline$c^{2}$ & & 0.02 & & & 0.000000593 & 0.01 \\
\hline Total heritability $\left(\mathrm{h}_{\mathrm{T}}^{2}\right)$ & 0.32 & 0.31 & 0.30 & 0.29 & 0.31 & 0.29 \\
\hline Log Likelihood & -185213.0 & -184154.2 & -184048.1 & -183868.2 & -184048.1 & -183866.1 \\
\hline
\end{tabular}

Despite the high direct heritability 0.57 estimate the total heritability was 0.30 due to the high negative direct maternal genetic covariance. The total heritability $(0.30)$ here is higher than values recorded by Bene et al. (2010), Szabo et al. (2012) in Hungarian beef calves. Meyer (1993) however, found similar estimate in Angus cattle.

As estimates from the various models show, evidently, allowing for covariance between direct and maternal effect increased the sampling variance dramatically. In particular, a level of cross substitution between parameters in the dataset was observed for Model 4 \& 6 compared to Model 3 and 5. In order to discern the likely reason, the additive genetic variance given maternal effects, $\sigma_{\text {A.M }}^{2}=\sigma_{\mathrm{A}}^{2}-\left(\sigma_{\mathrm{AM}}^{2} / \sigma_{\mathrm{M}}^{2}\right)$, as well as the conditional direct heritability, $\mathrm{h}^{2}{ }_{\mathrm{A} . \mathrm{M}}=\sigma_{\mathrm{A} . \mathrm{M}}^{2} /$ $\sigma^{2}$ was calculated. The resulting estimate (Table 2) suggests the problem of (co) sampling variation encountered when partitioning direct and maternal effects from additive genetic variance when they are assumed to be correlated. Meyer (1992) observed similar trend in crossbred Zebu. However, the inclusion of the sire by year interaction in subsequent research (Meyer, 1997a) reduced direct and maternal heritability estimate.

Table 2. Additive genetic variance given maternal effect $\sigma_{\mathrm{AM}}^{2} ; \boldsymbol{\sigma}_{\mathrm{A}}^{2}-\boldsymbol{\sigma}_{\mathrm{AM}}^{2} / \boldsymbol{\sigma}_{\mathrm{M}}^{2}$ estimates along with its resulting heritability $\left(\mathbf{h}_{\mathrm{AM}}^{2}\right)$, corresponding unconditional values are given for comparison

\begin{tabular}{|c|c|c|c|c|c|c|c|}
\hline \multirow{2}{*}{$\begin{array}{l}\text { Weaning } \\
\text { weight }\end{array}$} & & \multicolumn{4}{|c|}{ Genetic Parameters } & \multicolumn{2}{|c|}{ Genetic parameters* } \\
\hline & & Model 3 & Model 4 & Model 5 & Model 6 & Model 4 & Model 6 \\
\hline & $\sigma^{2}$ & 477.2 & 383.69 & 477.2 & 349.3 & 999.4 & 1002.6 \\
\hline & $\mathrm{h}^{2}$ & 0.28 & 0.23 & 0.28 & 0.20 & 0.57 & 0.58 \\
\hline
\end{tabular}

*unconditional values 
Estimation of direct maternal genetic correlation is considered as being inherently problematic (Robinson, 1996a; Meyer, 1997a; Phocas and Laloe, 2004) because they are partially confounded in the animal's performance (Robinson, 1996a; Phocas and Laloe, 2004). Negative direct maternal genetic correlation is often reported in literature (Van Niekerk, \& Neser, 2006; Bene et al., 2010; Jose et al., 2012; Araújo et al., 2010). Hence, the negative direct maternal genetic correlation $(-0.78)$ found here wasn't a surprise. Nevertheless, positive direct maternal genetic correlation have also been reported (De Oliveira, et al., 2021; Meyer, 1992; Dodenhoff et al., 1999). A negative direct maternal environmental covariance occurs when the daughter of a dam with high maternal ability provide an adverse environment effect to its offspring. This is often referred to as fatty udder syndrome (Mangus and Brinks, 1971) and it is believed to bias direct maternal genetic covariance estimate (Meyer, 1997b). Falconer (1965) and Meyer (1997a) fitted a regression on maternal phenotype to account for this covariance. A negative direct maternal genetic covariance is biologically plausible when there is genetic antagonism between genes responsible for direct and maternal effect. Lee and Pollak (2002) reported a negative correlation between milk yield and weaning weight in Hanwoo cattle which implies a genetic antagonism between direct and maternal effect. However, a negative strong direct maternal genetic covariance estimate is not believed to represent a true negative direct maternal genetic covariance as this estimate is believed to be biased by different causes
(Robinson, 1996b; Lee and Pollak, 2002; Meyer, 1997a). Mallinckrodt et al. (1995) demonstrated with simulated data that selective reporting biased direct maternal correlation estimates. Robinson (1996a) showed that the structure of the data as well as the inclusion of sire or sire by herd interaction can be important to produce unbiased estimates. Meyer (1997a) showed that omitting the fixed effect of paddock by year generated a high substantial negative direct maternal genetic correlation in experimental data. Although grandmaternal effect doesn't exist in some population, however, if they exist and they are not included in the model, direct and maternal correlation may be biased downward (Dodenhoff et al., 1999). Suárez and Cantet (2011) reported a direct maternal correlation value of -0.21 when grandmaternal was included and -0.71 when it was not grandmaternal effect wasn't included in Angus cattle. Therefore, it can be concluded that our model here may have not been comprehensive enough.

\section{CONCLUSIONS}

The genetic parameters estimate reported here corroborates the widespread dogma that estimating maternal effect is inherently problematic as they are confounded in animal's performance. The direct and maternal heritability values reported here are likely inflated, hence, further research is needed for proper partitioning of direct and maternal effect in order to achieve realistic genetic improvement.

\section{REFERENCES}

Anton, I.-Húth, B.-Füller, I.-Gábor, G.-Holló, G.-Zsolnai, A. (2018): Effect of single-nucleotide polymorphisms on the breeding value of fertility and breeding value of beef in Hungarian Simmental cattle. Acta Vet. Hung., 66 (2), 215-225.

Araújo, R.O.-Nogara Rorato, P.R.-Weber, T.-Everling, D.M.Lopes J.S.-Dornelles M.A. (2010): Genetic parameters and phenotypic and genetic trends for weight at weaning and visual scores during this phase estimated for Angus-Nellore crossbred young bulls. R. Bras. Zootec., 39 (11), 2398-2408.

Baldi, F.-Alencar, M.M.D.-Albuquerque, L.G.D. (2010) Estimativas de parâmetros genéticos para características de crescimento em bovinos da raça Canchim utilizando modelos de dimensão finita. R. Bras. Zootec., 39 (11), 2409-2417.

Bene, S.-Füller, I.-Fördős, A.-Szabo, F. (2010): Weaning results of beef Hungarian Fleckvieh calves 2. Genetic parameters breeding values. Arch. Anim. Breed., 53 (1), 26-36.

Boldt, R.J.-Speidel, S.E.-Thomas, M.G.-Enns, R.M. (2018) Genetic parameters for fertility and production traits in Red Angus cattle. J. Anim. Sci. 96 (10), 4100-4111.

Boligon, A.A.-Mercadante, M.E.Z.-Baldi, F.-Lôbo, R.B.Albuquerque, L.G. (2009): Multi-trait and random regression mature weight heritability and breeding value estimates in Nelore cattle. S. Afr. J. Anim. Sci., 39 (Supplement 1).

Brito, L.C-Peixoto, M.G.C.D.-Carrara, E.R.E.-Silva, F.F.-Ventura, H.T.-Bruneli, F.A.T.-Lopes, P.S. (2020): Genetic parameters for milk - growth - and reproductive traits in Guzerá cattle under tropical conditions. Trop. Anim. Health Prod., 52 (5), 22512257.

Campêlo, J.E.G.-Lopes, P.S.-Torres, R.D.A.-Silva, L.O.-Euclydes, R.F.-Araújo, C.V.D.-Pereira, C.S. (2004): Maternal effects on the genetic evaluation of Tabapuã beef cattle. Genet. Mol. Biol., 27(4), 517-521.

Crews, D.H.-Lowerison, J.M.-Caron, N.-Kemp, R.A. (2004): Genetic parameters among growth and carcass traits of Canadian Charolais cattle. Canadian J. Anim. Sci., 84 (4), 589-597.

Dadi, H.-Schoeman, S.J.-Jordaan, G.F. (2004): Estimation of (Co) variance components and genetic parameters of growth traits in beef cattle. J. Appl. Anim. Res., 26(2), 77-82.

De Oliveira, M.H.V.-De Vasconcelos Silva, J.A.I.-Da Silva Faria, R.A.-De Paiva, J.T.-Malheiros, J.M.-Dos Santos Correia, L.E.C.-De Genova Gaya, L. (2021): Genetic evaluation of weaning weight and udder score in Nellore cattle. Livest. Sci., 244, 104400 .

Dodenhoff, J.-Van Vleck, L.D.-Gregory, K.E. (1999): Estimation of direct - maternal - and grandmaternal genetic effects for weaning weight in several breeds of beef cattle. J. Anim. Sci., 77(4), 840-845

Eaglen, S.A.E.-Bijma, P. (2009): Genetic parameters of direct and maternal effects for calving ease in Dutch Holstein-Friesian cattle. J. Dairy Sci., 92 (5), 2229-2237. 
Falconer, D.S. (1965): Maternal effects and selection response. In: SJ. Geerts (Editor), Genetics Today, Pergamon Press, Oxford 763-774.

Gholizadeh, M.-Mianji, G.R.-Hashemi, M.-Hafezian, H. (2010): Genetic parameter estimates for birth and weaning weights in Raeini goats. Czech J. Anim. Sci., 55, 30-36.

Guidolin, D.G.F.-Buzanskas, M.E.-Ramos, S.B.-Venturini, G.C.Lôbo, R.B.-Paz, C.C.P.-Munari, D.P.-Oliveira, J.A. (2012) Genotype-environment interaction for post-weaning traits in Nellore beef cattle. Anim. Prod. Sci., 52, 975-980.

Herrera-Ojeda, J.B.-Parra-Bracamonte, G.M.-Lopez-Villalobos, N.-Martínez-González， J.C.-Magaña-Monforte， J.G.-Morris S.T.-López-Bustamante, L.A. (2019): Genetic variances and covariances of live weight traits in Charolais cattle by multi-trait analysis. J. Appl. Genet., 60 (3-4), 385-391.

Intaratham, W.-Koonawootrittriron, S.-Sopannarath, P.-Graser, H.U.-Tumwasorn, S. (2008): Genetic parameters and annual trends for birth and weaning weights of a Northeastern Thai indigenous cattle line. Asian-Australas J. Anim. Sci., 21 (4), 478-483.

Kamei, L.M.-De Azambuja Ribeiro, E.L.-Fonseca, N.A.N.-Muniz, C.A.D.-Camiloti, T.V.-Koritiaki, N.A.-De Souza Fortaleza, A.P. (2017): Genetic parameters of growth traits in Nellore cattle. Semina: Ciências Agrárias,38 (3), 1503-1509.

Kebede, D.-Komlosi, I. (2015): Evaluation of genetic parameters and growth traits of Hungarian Simmental cattle breed. Livest. Res. Rural. Dev., 27 (9).

Khombe, C.T.-Hayes, J.F.-Cue, R.I.-Wade, K.M. (1995): Estimation of direct additive and maternal additive genetic effects for weaning weight in Mashona cattle of Zimbabwe using an individual animal model. Anim. Sci., 60, 41-48.

Khorshidi, R.-Macneil, M.D.-Hays, D.P.-Abo-Ismail, M.K.Crowley, J.J.-Akanno, E.C.-Wang, Z.-Plastow, G. (2020): Estimation of genetic parameters and trends for growth traits in Hays Converter cattle using multiple-trait and random regression models. Livest. Sci., 241, 104245

Koch, R.M.-Clark, R.T. (1955): Genetic and environmental relationships among economic characters in beef cattle III. Evaluating maternal environment. J. Anim. Sci., 14 (4), 979996.

Lee, C.-Pollak, E.J. (2002): Genetic antagonism between body weight and milk production in beef cattle. J. Anim. Sci., 80(2), 316-321.

Legates, J.E. (1972): The role of maternal effects in animal breeding: IV. Maternal effects in laboratory species. J. Anim. Sci., 35 (6), 1294-1302.

Lopez, B.I.-Santiago, K.G.-Seo, K.-Jeong, T.-Park, J.E.-Chai, H.H.-Lim, D. (2020): Genetic Parameters of Birth Weight and Weaning Weight and Their Relationship with Gestation Length and Age at First Calving in Hanwoo (Bos taurus coreanae). Animals, 10 (6), 1083

Maiwashe, A.N.-Bradfield, M.J.-Theron, H.E.-Van Wyk, J.B (2002): Genetic parameter estimates for body measurements and growth traits in South African Bonsmara cattle. Liv. Prod. Sci., 75 (3), 293-300.

Mallinckrodt, C.H.-Golden, B.L.-Bourdon, R.M. (1995): The effect of selective reporting on estimates of weaning weight parameters in beef cattle. J. Anim. Sci., 73(5), 1264-1270.

Mangus, W.L.-Brinks, J.S. (1971): Relationships between direct and maternal effects on growth in Herefords: I. Environmental factors during preweaning growth. J. Anim. Sci., 32, 17-25.
Meyer, K. (1992): Variance components due to direct and maternal effects for growth traits of Australian beef cattle. Liv. Prod. Sci., 31 (3-4), 179-204.

Meyer, K. (1993): Estimates of covariance components for growth traits of Australian Charolais cattle. Aust. J. Agric. Res., 44 (7), 1501-1508.

Meyer, K. (1997a): Estimates of genetic parameters for weaning weight of beef cattle accounting for direct-maternal environmental covariances. Liv. Prod. Sci., 52 (3), 187-199.

Meyer, K. (1997b): Weaning weight revisited: Estimates of genetic parameters fitting a regression on maternal phenotype. In Proc. 12th Conf. Assoc. for the Advancement of Animal Breeding and Genetics - Dubbo - NSW - Australia. pp. 479-482.

Meyer, K. (2007): WOMBAT - A tool for mixed model analyses in quantitative genetics by REML - J. Zhejiang Univ. Sci. B 8: 815821. doi:10.1631/jzus.2007.B0815

Ndofor-Foleng, H.M.-Ebangi, A.L.-Agu, C.I.-Okenyi, N. (2012): Estimation of genetic parameters for preweaning and postweaning growth traits in the Gudali beef cattle using multiple trait derivative free restricted maximum likelihood. Afr. J. Biotechnol., 11 (78), 14410-14416.

Neser, F.W.C.-Van Wyk, J.B.-Fair, M.D.-Lubout, P.-Crook, B.J. (2012): Estimation of genetic parameters for growth traits in Brangus cattle. S. Afr. J. Anim. Sci. 42 (5): 469-473.

Phocas, F.-Laloe, D. (2004): Genetic parameters for birth and weaning traits in French specialized beef cattle breeds. Liv. Prod. Sci., $89,121-128$.

R Core Team. (2021): R: A language and environment for statistical computing. R Foundation for Statistical Computing - Vienna Austria. URL https://www.R-project.org/.

Robinson, D.L. (1996a): Estimation and interpretation of direct and maternal genetic parameters for weights of Australian Angus cattle. Liv. Prod. Sci., 45, 1-11.

Robinson, D.L. (1996b): Models which might explain negative correlations between direct and maternal genetic effects. Liv. Prod. Sci., 45(2-3), 111-22.

Robison, O.W. (1981): The influence of maternal effects on the efficiency of selection: A review. Liv. Prod. Sci. 8: 121-137.

Sarmiento, R.M.-Garcia, J.P. (2007): Estimation of genetic parameters and variance components for growth traits in Romosinuano cattle in the Colombian humid tropics. Genet. Mol. Res., 6(3), 482-491.

Silva, A.M.-Alencar, M.M.-Freitas, A.R.-Barbosa, R.T.-Barbosa, P.F.-De Sena Oliverira, M.C.-De Almeida Correa, L.-De Novaes, A.P.-Tullio, R.R. (2000): Herdabilidades e correlações genéticas para peso e perímetro escrotal de machos e características reprodutivas e de crescimento de fêmeas - na raça Canchim. R. Bras. Zootec., 29 (6), 2223-2230.

Skrypzeck, H.-Schoeman, S.J.-Jordaan, G.F.-Neser, F.W.C. (2000): Pre-weaning growth traits of the Hereford breed in a multibreed composite beef cattle population. S. Afr. J. Anim. Sci. - 2000: 30 (3): 220-229.

Suárez, M.J.-Cantet, R.J.C. (2011): Bayesian estimation in maternally ancestral animal models for weaning weight of beef cattle. J. Anim. Sci., 89(12), 3859-3871.

Szabo, F.-Lengyel, Z.-Domokos, Z.-Bene, S. (2007): Estimation of genetic parameters and (co)variance components for weaning traits of Charolais population in Hungary. Arch. Anim. Breed., 50 (5): 447-454.

Szabo, F.-Lengyel, Z.-Komlosi, I. (2002): Some effects on weaning weight of Hungarian Simmental Beef calves. $7^{\text {th }}$ World congress on Genetics applied to livestock production. Session 02 . 
Breeding ruminants for meat production. Communication: 2002. pp. 02-81.

Szabó, F.-Szabó, E.-Bene, S. (2012): Statistic and genetic parameters of 205-day weaning weight of beef calves. Arch. Anim. Breed., 55 (6), 552-561.

Szwaczkowski, T.-Wojtowski, J.-Stanislawska, E.- Gut, A. (2006) Estimates of maternal genetic and permanent environmental effects in sheep. Arch. Anim. Breed., 49, 186-192.

Tramonte, N.C.-Grupioni, N.V.-Stafuzza, N.B.-Guidolin, D.G.F.Savegnago, R.P.-Bezerra, L.A.F.-Lobo, R.B.-Munari, D.P. (2019): Genetic parameters - genetic trends - and principal component analysis for productive and reproductive traits of Guzera beef cattle. R. Bras. Zootec. 48.

Van Niekerk, M.-Neser, F.W.C. (2006): Genetic parameters for growth traits in South African Limousin cattle. S. Afr. J. Anim. Sci., 36: 6-9.
Vergara, O.D.-Ceron-Muñoz, M.F.-Arboleda, E.M.-Orozco, Y.-Ossa, G.A. (2009): Direct genetic maternal genetic and heterozygosity effects on weaning weight in a Colombian multibreed beef cattle population. J. Anim. Sci., 87 (2), 516-521.

Wasike, C.B.-Ilatsia, E.D.-Ojango, J.M.-Kahi, A.K. (2006): Genetic parameters for weaning weight of Kenyan Boran cattle accounting for direct-maternal genetic covariances. S. Afr. J. Anim. Sci., 36 (4), 275-281.

Wasike, C.B.-Indetie, D.-Ojango, J.M.-Kahi, A.K. (2009): Direct and maternal (co) variance components and genetic parameters for growth and reproductive traits in the Boran cattle in Kenya. Trop. Anim. Health Prod., 41 (5), 741-748.

Willham, R.C. (1972): The role of maternal effects in animal breeding III. Biometrical aspects of maternal effects in animals. J. Anim. Sci., 35, 1288-1293. doi:10.2527/jas1972.3561288x 